\title{
Newborn bath: construction and validation of the instrument content
}

\author{
Banho do recém-nascido: construção e validação de conteúdo de instrumento \\ Baño del recién nacido: construcción y validez de contenido de instrumento
}

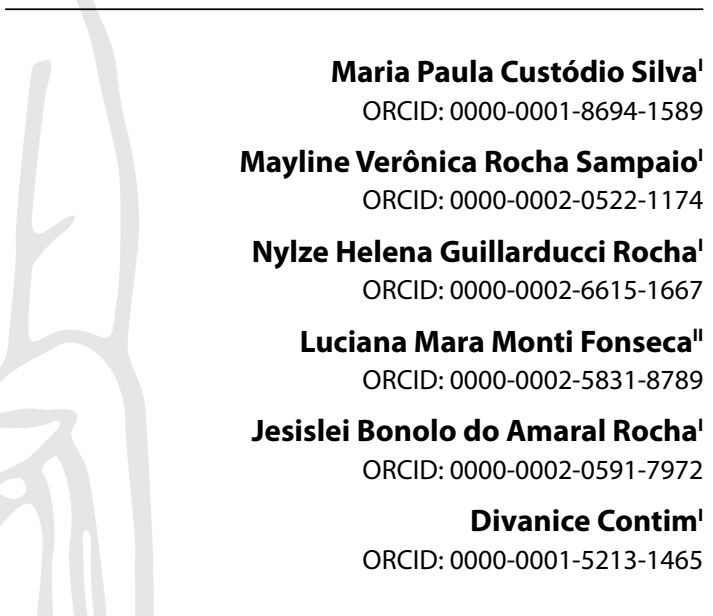

'Universidade Federal Triângulo Mineira. Uberaba, Minas Gerais, Brazil.

"Universidade de São Paulo. Ribeirão Preto, São Paulo, Brazil.

How to cite this article:

Silva MPC, Sampaio MVR, Rocha NHG, Fonseca LMM, Rocha JBA, Contim D. Newborn bath: construction and validation of the instrument content. Rev Bras Enferm. 2021;74(Suppl 4):e20200102. https://doi.org/10.1590/0034-7167-2020-0102

Corresponding author: Maria Paula Custódio silva E-mail:maria_paulacs@hotmail.com

EDITOR IN CHIEF: Antonio José de Almeida Filho ASSOCIATE EDITOR: Hugo Fernandes

\begin{abstract}
Objective: To build and validate the content of a good practice tool in the newborn bath Method: Methodological study, developed from December 2018 to January 2019, in a Joint Neonatal Housing Unit of a teaching hospital, in three stages: bibliographic survey, construction of the instrument and content validation by nine judges. The content validity index was used above $80 \%$ and general analysis with ten requirements. Results: The instrument was organized in three domains: before bathing, during bathing and after bathing, with a total of 20 items. Two rounds of validation were carried out to adjust the suggestions; the second presented a percentage of agreement between the judges, equal to or above 0.82. Conclusion: The instrument "Good practices in the newborn's bath" was considered representative and valid in terms of content.

Descriptors: Baths; Skin Care; Infant, Newborn; Nursing Care; Validation Studies.
\end{abstract}

\section{RESUMO}

Objetivo: Construir e validar o conteúdo de um instrumento de boas práticas no banho do recémnascido. Métodos: Estudo metodológico, desenvolvido no período de dezembro de 2018 a janeiro de 2019, em uma Unidade de Alojamento Conjunto Neonatal de um hospital de ensino, em três etapas: levantamento bibliográfico, construção do instrumento e validação de conteúdo por nove juízes. Empregou-se o índice de validade de conteúdo acima de $80 \%$ e análise geral com dez requisitos. Resultados: $O$ instrumento foi organizado em três domínios: cuidados antes do banho, durante o banho e após o banho, com tota de 20 itens. Foram realizadas duas rodadas de validação para adequações das sugestões; a segunda apresentou percentual de concordância entre os juízes igual ou superior a 0,82. Conclusão: $O$ instrumento "Boas práticas no banho do recém-nascido" foi considerado representativo e válido quanto ao conteúdo.

Descritores: Banhos; Higiene da Pele; Recém-Nascido; Cuidados de Enfermagem; Estudos de Validação.

\section{RESUMEN}

Objetivo: Construir y validar el contenido de un instrumento de buenas prácticas en el baño del recién nacido. Método: Estudio metodológico, desarrollado en el período de diciembre de 2018 a enero de 2019, en una Unidad de Alojamiento Conjunto Neonatal de un hospital de enseñanza, en tres etapas: levantamiento bibliográfico, construcción del instrumento y validez de contenido por nueve jueces. Se empleó el índice de validez de contenido arriba de $80 \%$ y análisis general con diez requisitos. Resultados: El instrumento ha sido organizado en tres dominios: cuidados antes del baño, durante el baño y después del baño, con el total de 20 ítems. Han sido realizadas dos rodadas de validez para adecuaciones de las sugestiones; la segunda presentó porcentual de concordancia entre los jueces igual o superior a 0,82. Conclusión: El instrumento "Buenas prácticas en el baño del recién nacido" ha sido considerado representativo y válido cuanto al contenido.

Descriptores: Baños; Higiene de la Piel; Recién Nacido; Cuidados de Enfermería; Estudios de Validez.
Approval: 09-30-2020

Submission: 04-07-2020 


\section{INTRODUCTION}

The newborn's bath (NB) is a practice permeated with expectations, challenges and meanings, in which the puerperal, besides meeting the hygiene needs of the child, promotes comfort, strengthens the bond and interaction between the mother and $N B^{(1)}$.Body hygiene is considered a challenging care, identified as a generator of doubts, due to the influence of cultural and socioeconomic conceptions of families and nursing professionals, who perform the orientations and care $\mathrm{c}^{(1-2)}$.

The nursing has used health education activities to the puerperal in order to perform them in a more adequate way and without risk to the baby. The permanence of the binomial in the Joint Neonatal Housing (JNH) is characterized as an important moment to guide the main cares of corporal hygiene and of the bath dispensed to the NB. Directions related to diaper change, hygiene of the umbilical stump, care regarding thermal imbalance at the time of bathing, support and incentive to breastfeeding are topics that should be addressed by the nursing team during the care provided to puerperals in $\mathrm{JNH}^{(3)}$.

The orientation of the first bath must be individual; and the procedure, demonstrated step by step to the puerperal, minimizing the stress caused to the NB, promoting greater security and link to the binomial. The subsequent baths are performed by the puerperal under supervision of the nursing team in order to clarify doubts and highlight relevant information ${ }^{(1) .}$

The maternal training, through the demonstration of the practice of standardized care minimizes the stress caused to the NB, without the occurrence of hypothermia, increased oxygen consumption, respiratory distress and alteration of vital signs. In addition, it promotes the family bond and makes the puerperal more secure to perform them at home ${ }^{(4-5)}$.

In the literature on the subject, doubts and difficulties were identified regarding the bath of $\mathrm{NB}^{(1-2,5-6)}$. There are reports of parents who were not able to carry out, during the period of hospitalization, the hygiene care (such as bath), because these were developed by the nursing team ${ }^{(4,7)}$. A study conducted in Portugal describes that the lack of practice or superficial guidance in the hospital environment negatively influences home care $^{(7)}$. To observe without practicing is not efficient; to evaluate the puerperal as to the correct execution of the cares allows to verify the level of understanding of the provided orientation, that is, if that care was or not interpreted adequately ${ }^{(7)}$.

The understanding of these aspects and the formulation of routines and protocols based on scientific evidence are essential to direct the execution of such procedure, establishing means for the organization of bath practice, making it safe for the NB in its process of adaptation to extra-uterine life ${ }^{(7-8)}$.

The purpose of this study is the construction and validation of an instrument that contributes and stimulates the adherence to safe practices related to the bathing of the NB, aiming at the improvement in the quality of assistance, the development of maternal autonomy in the care of your child and reflections that instrumentalize the puerperals during the maternity process. The use of checklists in nursing practice contributes to a better communication, less errors due to forgetfulness and allows the identification of fragilities and potentialities ${ }^{(9)}$, both of professionals and mothers, helping in the planning of orientations directed to the need of that service.

In view of the above, this study sought to answer the research question: What are the variables related to body hygiene in the NB can be an instrument of good practice for nurses to guide puerperals?

\section{OBJECTIVE}

Build and validate the content of a good practice tool in the newborn bath.

\section{METHODS}

\section{Ethical aspects}

The study was approved by the Research Ethics Committee of the Clinical Hospital of the Federal University of the Triângulo Mineiro, through submission to the Brazil Platform; and followed the recommendations of Resolution No. 466/12 of the National Health Council of Brazil.

\section{Design, study site and period}

A methodological study whose focus was on the construction and validation of the content of a good practice instrument in the bath of the NB, having been guided by the quality improvement studies-SQUIRE of the EQUATOR network and developed in the JNH unit of a teaching hospital in the state of Minas Gerais, a reference in the care of high complexity and high risk pregnant women. The unit has 14 inpatient beds, divided into six individual wards and four with two beds, with a monthly average of 150 deliveries.

Validating the content of an instrument means evaluating to what degree it measures what it proposes to measure. The validation of content allows the evaluation of clarity, ease of reading, comprehension and gauging of the intended items, proving the phenomenon of interest and the dimension of each item within what is intended to be investigated ${ }^{(10)}$. The theory of measuring instruments involves the composition of three procedures: theoretical, empirical (experimental) and analytical (statistical). The first refers to the creation of the construct, including elaboration of the items and validity of content; the second consists of the steps and techniques of application of pre-test or semantic analysis and pilot test; and the third relates to the statistical analysis used in validation ${ }^{(11)}$. In this study, the theoretical and analytical stage of content validation was carried out.

In view of these procedures, three steps were followed (Figure 1) for the eligibility of the construction parameters and instrument validation:

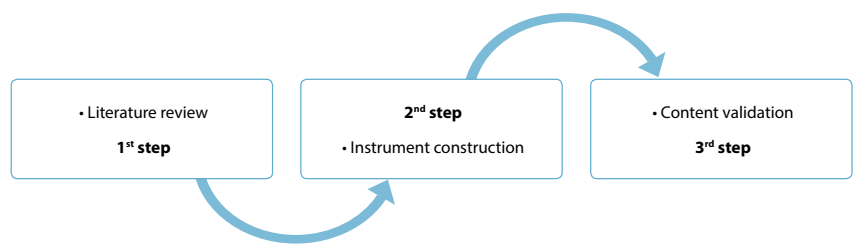

Figure 1 - Stages of the instrument elaboration, Uberaba, Minas Gerais, Brazil, 2020 
The data collection period for the content validation took place from December 2018 to January 2019.

\section{Population or sample, inclusion and exclusion criteria}

The selection of the judges was made through a search in the Lattes Platform of the National Council for Scientific and Technological Development (CNPq) website, considering the following criteria: doctoral degree, scientific production focused on the maternal-infant area and time of performance within the subject under discussion of five years or more. Judges who did not send the instrument in 15 days were excluded. Fifteen judges were invited to participate in the study, of which nine accepted and returned the evaluation in the stipulated period, five did not return in time, and one refused.

\section{Study protocol}

In the first stage, for the construction of the instrument, a bibliographic survey was conducted in the following databases: National Library of Medicine, Virtual Health Library, Cumulative Index to Nursing and Allied Health Literature, Scopus Info Site, Cochrane and Web of Science. In August 2018, the purpose was to identify the existing information in national and international literature related to the bath of NB. Studies published in Portuguese, English and Spanish were included, with a five-year timeline (2014 to 2018); and articles in other languages, expert opinion and letter to the editor were excluded. The following question guided this survey: What are the essential cares for the bath of NB?

The descriptors used in the Health Sciences Descriptors (DeCS) were: Newborn, Baths, Joint Housing, Knowledge, Mothers, Maternal Behavior and Mother-Son Relations. In Medical Subject Headings (MeSH), they were: Infant, Newborn*, Baths*, Rooming-in Care* $^{*}$, Knowledge, Mother*, Maternal Behavior*, Mother-Child Relations, with their respective synonyms. The search strategy was conditioned to the minimum combination of the descriptors "Newborn" and "Baths" together with other descriptors. Twentyeight articles were selected for full reading and extraction of data through Excel ${ }^{\circledR}$ spreadsheet, containing title, author, year, goal, methodological design and outcome.

Through this survey, the 2nd stage - elaboration and construction of the initial instrument for validation, consisting of three parts - was carried out:

Part I (seven questions) - Personal and professional identification of the judges: age, sex, institution in which they work, professional training, degree, sector in which they work and time spent working in maternal and child health.

Part II (22 questions) - Questions on the practice of bathing the NB divided into three areas: care before, during and after the bath. Each item was evaluated on the basis of the Likert type scale, so that each question presented five possibilities for answers to the weightings: I totally disagree, I partially disagree, I partially agree and I totally agree.

Part III (ten questions) - The general analysis of the instrument followed ten requirements: utility/pertinence, consistency, clarity, objectivity, simplicity, feasibility, updating, vocabulary, accuracy, instructional sequence of topics; at the end, the overall score ${ }^{(10)}$. The items of this step were evaluated on a scale from 1 to 10.
In the 3rd step, Google Forms was used to fill out the form in standard Hyper Text Markup Language (HTML) after sending an invitation letter by e-mail, containing the objectives of the study and the link to the Term of Free and Informed Consent along with the instrument to be evaluated. Given the consent to participate by selecting a specific item, the judge had access to the instrument, but if he did not agree to participate, the process was closed. The validation was done in two rounds by the same judges. It should be noted that at the end of each item, there was a blank field for suggestions and changes. -

\section{Analysis of results and statistics}

For statistical analysis of the validation data, they were extracted from Google Forms and stored in a database in Excel ${ }^{\circledast}$ format, by double input for further validation, processing and analysis. Consistency between judges was analyzed based on the content validity index $(\mathrm{CVI})$, considering a concordance above $80 \%{ }^{(10-11)}$. Suggestions for adjustments have been incorporated into the instrument.

\section{RESULTS}

Of the nine judges selected, all were female, nurses; nine (90\%) were professors at federal universities; and one (10\%) worked in a teaching hospital; they had a nine-year average time in the maternal and child care area.

The first version of the instrument, based on the results of the review, contained 22 items. After analysis of the first round of evaluation by judges, there was agreement among almost all items, and few were the changes.

In question 5 ("Check water temperature with a thermometer"), it was suggested to exclude it, since this is not a routine use in JNH nor in the home of puerperals; however, question 4 ("Check water temperature with the inside of the arm") was considered. In question 10 ("Hygiene the girl's genitalia from the anterior part to the posterior part, from the vaginal area to the rectal") and in question 11 ("Hygiene the boy's genitalia by washing the penile glans and the body of the penis with clean water"), the terms "genitalia" were replaced by "the intimate part", "from the anterior part to the posterior part" by "front to back"; and "penile glans" by "the tip of the penis". Because these two issues deal with actions of the intimate region, it was suggested "To perform intimate hygiene of the girl from front to back, from the vaginal area to the rectal; and of the boy, washing the tip and body of the penis with clean water".

In question 15, "Dry the umbilical stump with the tip of the diaper towel or gauze", it was recommended "Dry the umbilical stump with the tip of the diaper towel or gauze or cotton flexible stems and apply $70 \%$ alcohol protecting the surrounding skin". The cotton flexible stems were considered relevant because they are of routine use by families and health professionals. $70 \%$ alcohol is part of the unit's routine guidelines and was recommended by the judges. They suggested the following response options for the instrument: adequate care and inadequate care.

After this evaluation, 20 items were listed to compose the instrument, which was forwarded to the judges in order to reaffirm the changes. There were no divergences, so the issues remained and are presented in Table 1. 
Table 2 presents the ten general evaluation requirements of the instrument.

Table 1 - Description of the care evaluated by the nine judges considering the content validity index, Uberaba, Minas Gerais, Brazil, 2020

\begin{tabular}{|c|c|c|}
\hline \multicolumn{2}{|c|}{ Practical observation of the bath } & CVI \\
\hline \multicolumn{3}{|c|}{ Before the bath } \\
\hline & $\begin{array}{l}\text { Gather the necessary materials and leave them ready in a } \\
\text { safe place. }\end{array}$ & 0.92 \\
\hline 2 & Close doors and windows. & 0.92 \\
\hline 3 & Hygienize your hands. & 0.92 \\
\hline 4 & Check the water temperature with the inside of the arm. & 0.90 \\
\hline \multicolumn{3}{|c|}{ During the bath } \\
\hline & $\begin{array}{l}\text { Carry out facial and scalp cleansing before putting the baby } \\
\text { in water. }\end{array}$ & 0.92 \\
\hline & $\begin{array}{l}\text { Clean the eyes from inside out, using a cotton ball with } \\
\text { water in each eye. }\end{array}$ & 0.86 \\
\hline 7 & Clean the scalp with soap and water, without rubbing. & 0.92 \\
\hline & $\begin{array}{l}\text { Put the baby slowly in warm water and clean the neck, } \\
\text { upper limbs, anterior thorax, back and lower limbs } \\
\text { successively. }\end{array}$ & 0.92 \\
\hline 9 & $\begin{array}{l}\text { Clean the umbilical stump with soap and water during the } \\
\text { bath. }\end{array}$ & 0.88 \\
\hline 10 & $\begin{array}{l}\text { Perform intimate hygiene of the girl from front to back, from } \\
\text { the vaginal area to the rectal; and of the boy, washing the } \\
\text { tip and the body of the penis with clean water. }\end{array}$ & 0.82 \\
\hline \multicolumn{3}{|c|}{ After the bath } \\
\hline & Wrap the baby in a dry towel and take it to the safe place. & 0.92 \\
\hline & $\begin{array}{l}\text { Dry the skin and its folds with compressive and smooth } \\
\text { movements, without rubbing. }\end{array}$ & 0.92 \\
\hline & $\begin{array}{l}\text { Clean the nostrils with the tip of the bath towel or cotton } \\
\text { ball. }\end{array}$ & 0.90 \\
\hline 14 & $\begin{array}{l}\text { Carry out the cleaning of the ears externally and after them } \\
\text { with the index finger wrapped in the bath towel dampened } \\
\text { with water. }\end{array}$ & 0.86 \\
\hline 15 & $\begin{array}{l}\text { Dry the umbilical stump with the tip of the towel or gauze } \\
\text { or cotton flexible stems and apply } 70 \% \text { alcohol protecting } \\
\text { the surrounding skin. }\end{array}$ & 0.92 \\
\hline 16 & Use ointments in the perineum if there are signs of injury. & 0.92 \\
\hline 17 & Close the diaper below the umbilical stump. & 0.92 \\
\hline 18 & $\begin{array}{l}\text { Perform oral hygiene with your index finger wrapped in a } \\
\text { clean bath towel or gauze with filter water. }\end{array}$ & 0.82 \\
\hline & Talking to the baby/singing. & 0.90 \\
\hline \multirow[t]{2}{*}{20} & Breastfeeding the baby. & 0.90 \\
\hline & Global CVI & 0.94 \\
\hline
\end{tabular}

Note: CVI - content validity index.

Table 2 - General evaluation of the instrument by the nine judges, Uberaba, Minais Gerais, Brazil, 2020

\begin{tabular}{lc}
\hline Evaluated items & Average \\
\hline Utility/pertinence & 9.4 \\
Consistency & 8.7 \\
Clarity & 8.5 \\
Objetivity & 8.7 \\
Simplicity & 9.2 \\
Exequibility & 9.2 \\
Vocabulary & 9.2 \\
Update & 9.2 \\
Accuracy & 8.7 \\
Instructional sequence of topics & 9.0 \\
Global evaluation & 8.6 \\
\hline
\end{tabular}

\section{DISCUSSION}

The construction of instruments in several research areas has become common and has great influence on decisions about care, treatment and/or interventions and on the formulation of health programs and institutional policies ${ }^{(12-13)}$. However, the scarcity of instruments on the subject motivated the elaboration of this study.

The judges' concern in contemplating the main stages of the bath in an objective manner and with accessible language resulted in an instrument with 20 items, divided into three domains: care before the bath, during the bath and after the bath.

The Pasquali model used in the construction and validation process has been used in several studies in the field of nursing, allowing delimiting the instrument items with clarity, uniformity and reliability ${ }^{(13-16)}$.

In the content validation stage, six to 20 judges and a minimum of three for each group of selected professionals are recommended; the use of odd numbers avoids a tie of opinions ${ }^{(11,13)}$. Therefore, the quantity used in this study was sufficient. As for the response options, the Likert scale allows to evaluate different degrees of agreement and is widely used to measure opinions, beliefs or attitudes ${ }^{(17)}$.

The evaluation through Pasquali's ten requirements contributes to the reliability and reliability of the instrument, being recommended number above eight ${ }^{(11)}$. For reliability among judges, the CVI was used, which has been one of the most used criteria for deciding on the relevance of items, considering as acceptable values above $80 \%{ }^{(16-18)}$.

Regarding the composition of the items, the domain "before the bath" brings care of safety and water temperature. The practice of gathering the necessary materials and leaving them prepared in an adequate place and close to the executor are important measures for the safety of the procedure and of the NB, avoiding situations that predispose the occurrence of accidents ${ }^{(4,19)}$. The importance of hand hygiene to reduce infections is stressed ${ }^{(20)}$.

The bathing place must remain air-conditioned with closed doors and windows to avoid draughts that promote temperature variations in the environment and favor heat loss by the NB, compromising its thermal stability ${ }^{(19)}$. The verification of the water temperature can be performed with the inner part of the arm, area of greater thermal sensitivity, or with a thermometer, when available ${ }^{(21)}$. The verification of the water temperature can be performed with the inner part of the arm, area of greater thermal sensitivity, or with a thermometer, when available.

The care items during the bath included the actions that must be performed during the procedure. It is recommended to clean the face with clean and soap-free water, before the immersion of the NB in water ${ }^{(22-23)}$. Eye hygiene should be performed from the inner corner to the outer corner in order to avoid contamination and can be performed with cotton balls moistened with clean water $^{(23)}$. The scalp can be sanitized with the baby wrapped in a diaper towel or at the end of the bath to reduce the impact of hypothermia; it should be washed with water, neutral soap and gentle movements, without rubbing ${ }^{(22)}$.

The contact of the NB with water should occur slowly and gradually to reduce the impact of stress caused by cold ${ }^{(23)}$. The cleaning of the genital region should start in the anteroposterior direction to prevent the dissemination of microorganisms ${ }^{(19,23)}$.

After bath care items included drying the NB using a clean, dry diaper towel, with gentle compressive movements, to avoid 
excessive humidity and friction with the skin, favoring cellular integrity and maintenance of the protective function ${ }^{(24-25)}$. The towel should be close to the bathing area and easily accessible so that the baby is not exposed to temperature variations ${ }^{(26)}$.

As for the nostrils and ears, the use of flexible cotton rods should be avoided because of the risk of injuries. Regarding the oral hygiene of the NB, the judges' evaluation indicated the use of filtered water and moistened gauze to decrease the risk of infections, such as oral candidiasis ${ }^{(20)}$.

In relation to the umbilical stump, keeping it only clean and dry has proven effective, since the use of alcoholic substances can cause possible damage to the skin, however this is still a common practice ${ }^{(27-29)}$. In this study, the application of $70 \%$ alcohol was considered important by the judges and is used in the unit investigated. In countries and regions of low income, its use or of $0.5 \%$ alcohol chlorhexidine plays an important role in reducing the microbial load and omphalitis ${ }^{(20,30)}$.

The diaper should be closed below the umbilical stump to allow contact with oxygen, favoring angiogenesis and stimulating the healing process ${ }^{(31)}$. The use of ointments and emollients in the intact perineum for the prevention of dermatitis is a common practice, although there are no studies that prove its effectiveness when used routinely, considering that the additives of the composition can generate irritation and toxicity when in contact with the skin of the $\mathrm{NB}^{(32-33)}$.

Talking to RN and singing to him while offering the care favors the recognition of the mother as a caregiver, contributing to the safe and healthy bio-psycho-affective development, allowing her greater peace of mind and self-confidence in the execution of the procedure ${ }^{(34)}$. Placing the NB to breastfeed soon after the bath stimulates skin to skin contact, strengthening the bond, maintaining the stability of the cardiorespiratory system and reducing stress caused by cold due to the unbalance between production and loss of heat by the $\mathrm{NB}^{(35)}$.

The period of hospitalization in $\mathrm{JNH}$ is usually from 24 to 48 hours, an opportune time to accomplish these orientations, however it must be considered that the new task for the parents can be difficult to assimilate due to the fragility and crying of the baby, which make them insecure and anxious. In this sense, it is suggested the incorporation of educational strategies also during the prenatal period, when there is enough time for them to clear up doubts and carry out simulated trainings ${ }^{(2)}$.

Thus, after all the validation stages were completed, the items of the instrument were considered valid in terms of content, because they contemplated the scores recommended by the benchmark adopted in this research ${ }^{(11)}$.

\section{Limitations of study}

As a limitation, in this study, the empirical phase of the instrument elaboration and factor analysis theory was not carried out at the appropriate time.

\section{Contributions to nursing, health or public policy}

The construction and validation of the content of the instrument "Good practices in the bath of the NB" has the contribution of offering a complementary technology to the evaluation of the bath practice and the hygiene care provided to the NB during its stay in $\mathrm{JHN}$, favoring the process of health education carried out with mothers during the immediate puerperium. Furthermore, it will contribute to the improvement of the quality of nursing care provided to the binomial.

\section{CONCLUSION}

The study made possible the construction and validation of the content of the instrument "Good practices in the bath of NB", which approached the necessary steps of its preparation and execution. The agreement among the judges reached the values considered adequate; through the general analysis, it was possible to evaluate the utility/pertinence, consistency, clarity, objectivity, simplicity, feasibility, updating, vocabulary, precision and instructional sequence of the topics, allowing the material produced to be the starting point for other stages of analysis.-

\section{FUNDING}

This research received funding through the Fundação de Amparo à Pesquisa de Minas Gerais-FAPEMIG, n 11770-2018.

\section{REFERENCES}

1. Silva CMS, Dantas JC, Souza FMLC, Silva RAR, Lopes TRG, Carvalho JBL. Sentimentos vivenciados por puérperas na realização do primeiro banho do recém-nascido no alojamento conjunto. Mundo Saúde. 2015;39(3):279-86. https://doi.org/10.15343/0104-7809.20153903279286

2. Vasconcelos ML, Pessoa VLMP, Chaves EMC, Pitombeira MGV, Moreira TMM, Cruz MR et al. Care for children under six months at domicile: primiparae mother's experience. Esc Anna Nery. 2019;23(3):e20180175. https://doi.org/10.1590/2177-9465-EAN-2018-0175

3. Mercado NC, Souza GDS, Silva MMJ, Anseloni MG. Nursing care and guidelines for puerperae in rooming-in. Rev Enferm UFPE. 2017;11(9):3508-15. https://doi.org/10.5205/reuol.10620-94529-1-SM.1109sup201702

4. Brogan J, Rapkin G. Implementing evidence-based neonatal skin care with parent-performed, delayed immersion baths. Nurs Womens Health. 2017;21(6):442-50. https://doi.org/10.1016/j.nwh.2017.10.009

5. Gomes ALM, Rocha CR, Henrique DM, Santos MA, Silva LR. Conhecimentos de familiares sobre os cuidados com recém-nascidos. Rev Rene. 2015;16(2):258-65. https://doi.org/10.15253/2175-6783.2015000200016

6. Duarte F, Góes F, Rocha A, Ferraz J, Moraes J, Silva L. Preparing for discharge of low-risk newborns to home care. Rev Enferm UERJ. 2019;27:e38523. https://doi.org/10.12957/reuerj.2019.38523 
7. Silva CS, Carneiro MNF. First-time parents: acquisition of parenting skills. Acta Paul Enferm. 2018;31(4):366-73. https://doi. org/10.1590/1982-0194201800052

8. Vieira BC, Backes MTS, Costa LD, Fernandes VMB, Dias HHZR, Backes DS. Applying best practices to pregnant women in the obstetric center. Rev Bras Enferm. 2019;72(Suppl 3):191-96. https://doi.org/10.1590/0034-7167-2018-0422

9. Amaya MR, Paixão DPSS, Sarquis LMM, Cruz EDA. Construction and content validation of checklist for patient safety in emergency care. Rev Gaúcha Enferm. 2016;37(spe):e68778. https://doi.org/10.1590/1983-1447.2016.esp.68778

10. Polit DF, Beck CT. Fundamentos de pesquisa em enfermagem: avaliação de evidências para a prática da enfermagem. 9. ed. Porto Alegre: Artmed. 2019.

11. Pasquali L. Instrumentação psicológica: Fundamentos e práticas. Porto Alegre, Brasil: Artmed. 2010.

12. Coluci MZO, Alexandre NMC, Milani D. Construção de instrumentos de medida na área da saúde. Ciênc Saúde Coletiva. 2015;20(3):925-36. https://doi.org/10.1590/141381232015203.04332013

13. Medeiros RKS, Ferreira JMA, Pinto DPSR, Vitor AF, Santos VEP, Barichello E. Modelo de validação de conteúdo de Pasquali nas pesquisas em Enfermagem. Rev Enferm Ref. 2015;serIV (4):127-35. https://doi.org/10.12707/RIV14009

14. Nora CRD, Zoboli E, Vieira MM. Validação por peritos: importância na tradução e adaptação de instrumentos. Rev Gaúcha Enferm. 2017;38(3):e64851. https://doi.org/10.1590/19831447.2017.03.64851

15. Santos KC, Fonseca DF, Oliveira PP, Duarte AGS, Melo JMA, Souza RS. Men's health care: construction and validation of a tool for nursing consultation. Rev Bras Enferm. 2020;73(3):e20190013. https://doi.org/10.1590/0034-7167-2019-0013

16. Tolentino GS, Bettencourt ARC, Fonseca SM. Construction and validation of an instrument for nursing consultation in outpatient chemotherapy. Rev Bras Enferm. 2019;72(2):391-9. https://doi.org/10.1590/0034-7167-2018-0031

17. Lemos CS, Poveda VB, Peniche ACG. Construction and validation of a nursing care protocol in anesthesia. Rev Latino-Am Enfermagem. 2017;25:e2952. https://doi.org/10.1590/1518-8345.2143.2952

18. Mendes CQS, Mandetta MA, Tsunemi MH, Balieiro MMFG. Adaptação transcultural do Preterm Parenting \& Self-Efficacy Checklist. Rev Bras Enferm. 2019;72(Suppl 3):274-81. https://doi.org/10.1590/0034-7167-2018-0658

19. Ruschel LM, Pedrini DB, Cunha MLC. Hypothermia and the newborn's bath in the first hours of life. Rev Gaúcha Enferm. 2018;(39):e20170263. https://doi.org/10.1590/1983-1447.2018.20170263

20. Lima RO, Estevam LD, Leite FMC, Almeida MVIS, Nascimento L, Amorim MHC et al. Nursing intervention first bath of the NB: a randomized study on neonatal behavior. Acta Paul Enferm. 2020;33:e-APE20190031. https://doi.org/10.37689/acta-ape/2020ao0031

21. Ar l, Gözen D. Effects of underrunning water bathing and immersion tub bathing on vital signs of newborn infants. Adv Neonatal Care. 2018;18(6),03-12. https://doi.org/10.1097/anc.0000000000000484

22. Freitas $\mathrm{P}, \mathrm{Munhoz} M \mathrm{MB}$, Costa $\mathrm{P}$, Kimura AF. Effect of two immersion bathing techniques on the axillary temperature of preterm newborns: a pilot study. Texto Contexto Enferm. 2018;27(1):e0580016. https://doi.org/10.1590/0104-070720180000580016

23. Paulela DC, Bocchi SCM, Mondelli AL, Martin LC, Sobrinho AR. Effectiveness of bag bath on microbial load: clinical trial. Acta Paul Enferm. 2018;31(1):7-16. https://doi.org/10.1590/1982-0194201800003

24. Aredes NDA, Santos RCA, Fonseca LMM. Skin care of the newborn: the state of art. Rev eletrônica enferm. 2017;(19):a59. https://doi. org/10.5216/ree.v19.43331

25. Martins COA, Curado MAS. Escala de observação do risco de lesão da pele em neonatos: validação estatística com recém-nascidos. Rev Enferm Ref. 2017;13(4):43-52. https://doi.org/10.12707/RIV16082

26. Albuquerque RS, Mariani Neto C, Bersusa AAS, Dias VM, Silva MIM. Newborns' temperature submitted to radiant heat and to the Top Maternal device at birth. Rev Latino-Am Enfermagem. 2016;(24):e2741. https://doi.org/10.1590/1518-8345.0305.2741

27. Quattrin R, lacobucci K, Tina AL, Gallina L, Pittini C, Brusaferro S. $70 \%$ alcohol versus dry cord care in the umbilical cord care: a case-control study in Italy. Medicine. 2016;95(14):e3207. https://doi.org/10.1097/MD.0000000000003207

28. Barbosa M, Moreira S, Ferreira S. Desinfeção do cordão umbilical: revisão baseada na evidência. Rev Port Med Geral Fam [Internet]. 2017 [cited 2020 Feb 10];(33):41-7. Available from: http://www.scielo.mec.pt/pdf/rpmgf/v33n1/v33n1a05.pdf

29. Khalifian S, Golden WC, Cohen BA. Skin care practices in newborn nurseries and mother-baby units in Maryland. J. Perinatol. 2016;(o):1-7. https://doi.org/10.1038/jp.2016.226

30. Miranda J, Santos D, Camargo C, Santa-Rosa D, Sobrinho C, Mussi F. Evidence for umbilical stump care practices: integrative review. Rev Enferm UFPE. 2016;10(2):821-9. https://doi.org/10.5205/1981-8963-v10i2a11025p821-829-2016

31. Andrade SM, Santos ICRV. Hyperbaric oxygen therapy for wound care. Rev Gaúcha Enferm. 2016;37(2):e59257. https://doi. org/10.1590/1983-1447.2016.02.59257

32. Santos SV, Costa R. Prevention of newborn skin lesions: knowledge of the nursing team. Texto Contexto Enferm. 2015;24(3):731-9. https:// doi.org/10.1590/0104-0707201501123_014

33. Brondani KJM, Ferrari RAP, Cardelli AAM, Tacla MTGM, Fançoso FG, Dalmas JC. Práticas maternas e uso de terapias alternativas no cuidado da criança. Cogitare Enferm. 2018;(23)4:e54090. https://doi.org/10.5380/ce.v23i4.54090 
34. Silva BAA, Braga LP. Fatores promotores do vínculo mãe-bebê no puerpério imediato hospitalar: uma revisão integrativa. Rev SBPH [Internet]. 2019 [cited 2020 Feb 10];22(1):258-79. Available from: http://pepsic.bvsalud.org/pdf/rsbph/v22n1/v22n1a14.pdf

35. Sampaio ARR, Bousquat A, Barros C. Skin-to-skin contact at birth: a challenge for promoting breastfeeding in a "Baby Friendly" public maternity hospital in Northeast Brazil. Epidemiol Serv Saude. 2016;25(2):281-90. https://doi.org/10.5123/S1679-49742016000200007 